\title{
o5. Perceptions of the authors writing book sets for teaching Turkish as a foreign language on the process of writing a book
}

\section{İbrahim GÜLTEKİN}

APA: Gültekin, İ. (2021). Perceptions of the authors writing book sets for teaching Turkish as a foreign language on the process of writing a book. RumeliDE Dil ve Edebiyat Araştırmaları Dergisi, (24), 55-76. DOI: 10.29000/rumelide.990081.

\begin{abstract}
Coursebook is described as an important and functional tool in teaching Turkish as a foreign language. Instructors, learners and testers consider the coursebook, which is prepared in accordance with the curriculum, as an important material for constructing the teaching process of the target language and following the assessment and evaluation stages. When the literature is analyzed, it is understood that many studies have been carried out in different contexts on coursebooks prepared for teaching Turkish as a foreign language. In this study, coursebooks are discussed in the dimension of authors. The aim of the study is to determine the perceptions of the authors writing under the roof of Turkish Maarif Foundation, which enabled the first book to be written within the scope of formal education based on the Curriculum for Teaching Turkish as a Foreign Language, regarding the process of writing a book. The study group of the research consists of twenty-two participants. As one of the qualitative research methods, phenomenology was used to determine the perceptions of the participants about the writing process of coursebooks. A semi-structured interview form was used to collect the data, and the content analysis was used in the analysis process. Accordingly, findings of the research were categorized under five main headings as being the principles of preparing the coursebook, the experiences experienced during the process, the characteristics of the texts to be selected for the coursebook, the qualities of the exercises in the coursebook, and the feature of the coursebook as a set.
\end{abstract}

Keywords: Teaching Turkish as a foreign language, coursebook, coursebook author, Turkish Maarif Foundation

\section{Türkçenin yabancı dil olarak öğretimine yönelik kitap setleri hazırlayan yazarların kitap yazım sürecine yönelik algıları}

\section{$\ddot{O} \mathbf{z}$}

Ders kitabı, Türkçenin yabancı dil olarak öğretiminde önemli ve işlevsel bir araç olarak nitelenmektedir. Öğretici, öğrenici ve sınav uygulayıcıları, müfredata uygun olarak hazırlanmış ders kitabını hedef dilin öğretim sürecini inşa etmek, ölçme ve değerlendirme aşamaları takip etmek için önemli bir materyal olarak görmektedir. Alanyazın incelendiğinde Türkçenin yabancı dil olarak öğretimine yönelik hazırlanan ders kitapları üzerine farklı bağlamlarda pek çok çalışmanın yapıldığı anlaşılmaktadır. Bu çalışmada ise ders kitapları, kitap yazarları boyutunda ele alınmaktadır. Çalışmanın amacı, Türkçenin Yabancı Dil Olarak Öğretimi Programı’nı esas alarak örgün eğitim kapsamında ilk defa kitap yazılmasını sağlayan Türkiye Maarif Vakfı bünyesindeki yazarların, kitap yazma sürecine ilişkin algılarını belirlemektir. Araştırmanın çalışma kümesini yirmi iki katılımcı

Doç. Dr. Kırıkkale Üniversitesi, Eğitim Fakültesi, Türkçe ve Sosyal Bilimler Eğitimi Bölümü, (Kırıkkale, Türkiye), ibogultekin2000@yahoo.com, ORCID ID: 0000-0002-6084-7129 [Araştırma makalesi, Makale kayit tarihi: 20.06.2021kabul tarihi: 20.09.2021; DOI: 10.29000/rumelide.990081]

Adres | Address

RumeliDE Dil ve Edebiyat Araşturmalar Dergisi $\quad$ RumeliDE Journal of Language and Literature Studies Osmanağa Mahallesi, Mürver Çiçeği Sokak, No:14/8 Osmanağa Mahallesi, Mürver Çiçeği Sokak, No:14/8 Kadıköy - ÍSTANBUL / TÜRKIYE 34714 Kadıköy - ISTANBUL / TURKEY 34714 e-posta: editor@rumelide.com e-mail: editor@rumelide.com, tel: +90 $5057958124,+902167730616$ phone: +90 505 7958124, +90 2167730616 
Perceptions of the authors writing book sets for teaching Turkish as a foreign language on the process of writing a book / $\dot{\mathrm{I}}$. Gültekin (pp. 55-76)

oluşturmaktadır. Katılımcıların, ders kitabı yazma sürecine ilişkin algılarını belirlemek için nitel araştırma yöntemlerinden olgubilim kullanılmıştır. Verilerin toplanmasında yarı yapılandırılmış görüşme formu kullanılmış, analiz sürecinde ise içerik analizinden faydalanılmıştır. Buna göre araştırma bulguları; ders kitabı hazırlama ilkeleri, süreçte yaşananlar, ders kitabına seçilecek metinlerin özellikleri, ders kitabındaki etkinliklerin nitelikleri ve ders kitabının set olma özelliği olmak üzere beş ana başlık altında toplanmıştır.

Anahtar kelimeler: Türkçenin yabancı dil olarak öğretimi, ders kitabı, ders kitabı yazarı, Türkiye Maarif Vakfi

\section{Introduction}

The basic material in teaching Turkish as a foreign language is the book sets prepared in accordance with the levels of the language. These book sets can consist of a coursebook, a workbook and a teacher's guidebook, or they can only consist of a coursebook and a workbook, or a coursebook and a teacher's guidebook.

A course book is a course material that systematically presents the information accepted by the experts and practitioners of the relevant field on the basis of a certain curriculum (Yalçın, 1994). It is known that many book sets have been prepared by different institutions and organizations, especially TÖMERs of universities, regarding the teaching of Turkish as a foreign language. While Özbay (2003) states that the most commonly used material by teachers in the classroom is the coursebook, Arl (2014) states that the most important course tool used by the students is the coursebook. Nowadays, the rapid development of technology also directly affects educational technology and tools. This process of change and transformation directly affects learning environments and the diversity of the use of materials by teachers and learners in a positive way. For example, in today's conditions, learning gains flexibility in place, time and environment and progresses in a dynamic process by using mobile tools. By any means, it is also known that a systematic content is always needed for a systematic learning. It reveals that coursebooks do not lose their quality as the main reference source for teachers and students (Kolaç:2003).

Coursebook provides concrete and measurable progress for the teaching process, teachers, and students. Teaching process is carried out gradually in accordance with the curriculum through a coursebook built on a specific well-structured teaching system. The teacher plans the teaching process by following the coursebook and uses the time effectively and efficiently. Assessment and evaluation are structured on healthy and objective criteria. The coursebook guides the student about what, when and how to learn. In this context, it is possible to say that preparing coursebooks in a quality way is highly important.

The quality of the books written for the purpose of teaching Turkish as a foreign language turns into a variable determining the extent to which the learners will learn the target language. In this sense, those who write coursebooks are expected to be aware of their responsibilities. The qualities that Turkish coursebooks prepared for native speakers should have are specified in the curriculum prepared for the Turkish lesson (MEB, 2006; 2019). However, there are not any criteria on what kind of qualities the books prepared for teaching Turkish as a foreign language should have. Hengirmen (1993) specifies the criteria to be considered in coursebooks aiming to teach Turkish as a foreign language as follows:

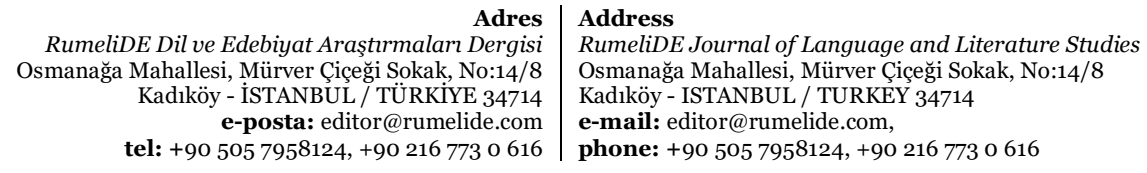


- The content of the book should be designed in accordance with the most needed topics in daily life.

- The content of the book should be organized in a way that shall improve the listening, speaking, reading and writing skills of the learners, and grammar topics should be included in a way that supports the development of these skills.

- The content of the book should be supported with visuals that facilitate learning.

Although it is not possible to talk about specific criteria accepted by everyone in the writing of the coursebooks prepared for the teaching of Turkish as a foreign language, it can be stated that the existing books in the field are prepared based on the language levels specified in the Common European Framework of Reference for Languages and the competencies required by these levels in order to ensure standardization in language teaching. On the other hand, the Common European Framework of Reference for Languages has been used as a reference text not only in the preparation of coursebooks, but also in the implementation, and assessment and evaluation processes. The main reason for this is that there is not any common curriculum for teaching Turkish as a foreign language, on which all institutions and practitioners agree, apart from the project-based curriculum study prepared by Ankara University TÖMER (2015). In the conducted studies, it is emphasized that the lack of program or curriculum in teaching Turkish as a foreign language is the most important deficiency of the field (Candaş Karababa, 2009; Durukan and Maden, 2013; Durmuş, 2013; Biçer, Çoban and Bakır, 2014; Demirtaş and Acer, 2016; Balc1, 2017) because unless there is a curriculum, the teaching process, writing of book sets, and the assessment and evaluation processes shall not progress at any standard.

Established with a special law numbered 6721 in order to carry out educational activities abroad, Turkish Maarif Foundation pioneered the teaching of Turkish as a foreign language, and prepared the Curriculum for Teaching Turkish as a Foreign Language between the years of 2018 and 2019 with a working group consisting of academicians, practitioners and institution representatives; and this curriculum was approved by the No. 36 decision of the Ministry of Education's Board of Education and Discipline under the date of 11.11.2020. It is certain that the mentioned curriculum shall provide the standard of education and training activities carried out in the field (Balcı and Melanlıoğlu, 2020). Therefore, in order to meet these standards, it is necessary to prepare the coursebooks written for the purpose of teaching Turkish as a foreign language by taking MoNE approved the Curriculum for Teaching Turkish as a Foreign Language into account.

How should the coursebooks prepared for teaching Turkish as a foreign language be? It would be appropriate to seek a curriculum oriented answer to this question. Developed on the basis of the Common European Framework of Reference for Languages, the Curriculum for Teaching Turkish as a Foreign Language was prepared as a teaching curriculum based on an action-oriented approach, which regulates the basic foundations and approaches, objectives, achievements in accordance with levels and skills, assessment and evaluation process, and the content of language teaching, and structures language teaching standards within a certain framework for those who learn Turkish within the scope of formal and non-formal education in Turkey or abroad, for instructors, for those who prepare teaching materials, and for testers (TYDÖP, 2020, p. 10). In this context, the general objectives mentioned in the Curriculum for Teaching Turkish as a Foreign Language are as follows:

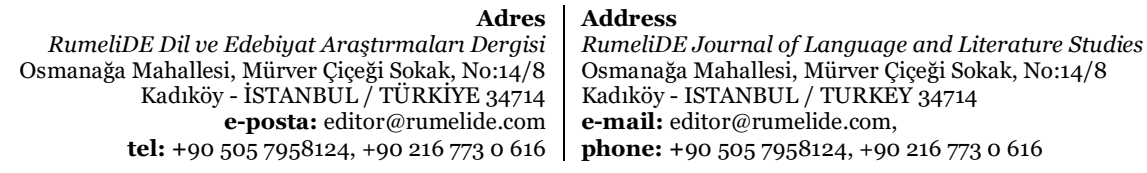

RumeliDE Dil ve Edebiyat Araşturmalar Dergisi Kadıöy - ISTANBUS / TÜRKIYE 34714 tel: +90 505 7958124, +902167730616 
It is aimed;

- To develop Turkish comprehension skills through listening/watching and reading,

- To develop Turkish speaking skills through oral production, oral interaction and writing,

- To enable students to consciously, correctly and carefully use their listening, speaking, reading and writing skills in a holistic manner and in accordance with the rules,

- To help students gain nonverbal communication skills in Turkish and to enable them to use them correctly in communication processes,

- To enrich Turkish vocabulary,

- To gain cultural sensitivity through interaction,

- To enable them to recognize the distinguished works of Turkish language and literature,

- To develop lifelong learning skills,

- To enable them to acquire/develop 21st century skills with an interdisciplinary approach,

- Developing academic and special-purpose Turkish language proficiency

of students.

Considering the general objectives mentioned above, it can be stated that the aim is to develop learners, who learn Turkish as the target language, in terms of life skills as well as enabling them to become competent in language skills. It can be stated that this priority of the curriculum must be reflected in the coursebooks to be prepared.

One of the most important aspects of the Curriculum for Teaching Turkish as a Foreign Language is that it includes syllabuses covering all stages of formal education including pre-school, primary school, secondary school and high school as well as determining the achievements according to levels and skills. In the curriculum, the language learning process and levels differ for each level. The syllabus of the curriculum for formal education was structured in two dimensions by taking the education process in Turkey and abroad into account by levels. In this respect, one of the criteria determining the content of the prepared book is whether the target audience learns Turkish in Turkey or abroad. The scope of the book shall also vary as the course hours differ in accordance with where Turkish is learned/taught. In order to clarify the aforementioned point, information about the domestic implementation of the Curriculum for Teaching Turkish as a Foreign Language is presented in Table 1.

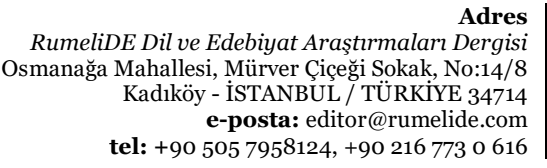

Adres

RumeliDE Dil ve Edebiyat Araştırmaları Dergisi Kadıköy - İSTANBUL / TÜRKIYE 34714 tel: +90 505 7958124, +902167730616
Address

RumeliDE Journal of Language and Literature Studies

Osmanağa Mahallesi, Mürver Çiçeği Sokak, No:14/8

Kadıköy - ISTANBUL / TURKEY 34714

e-mail: editor@rumelide.com,

phone: +90 $5057958124,+902167730616$ 
Table 1. Domestic Structuring of the Curriculum for Teaching Turkish as a Foreign Language by Levels

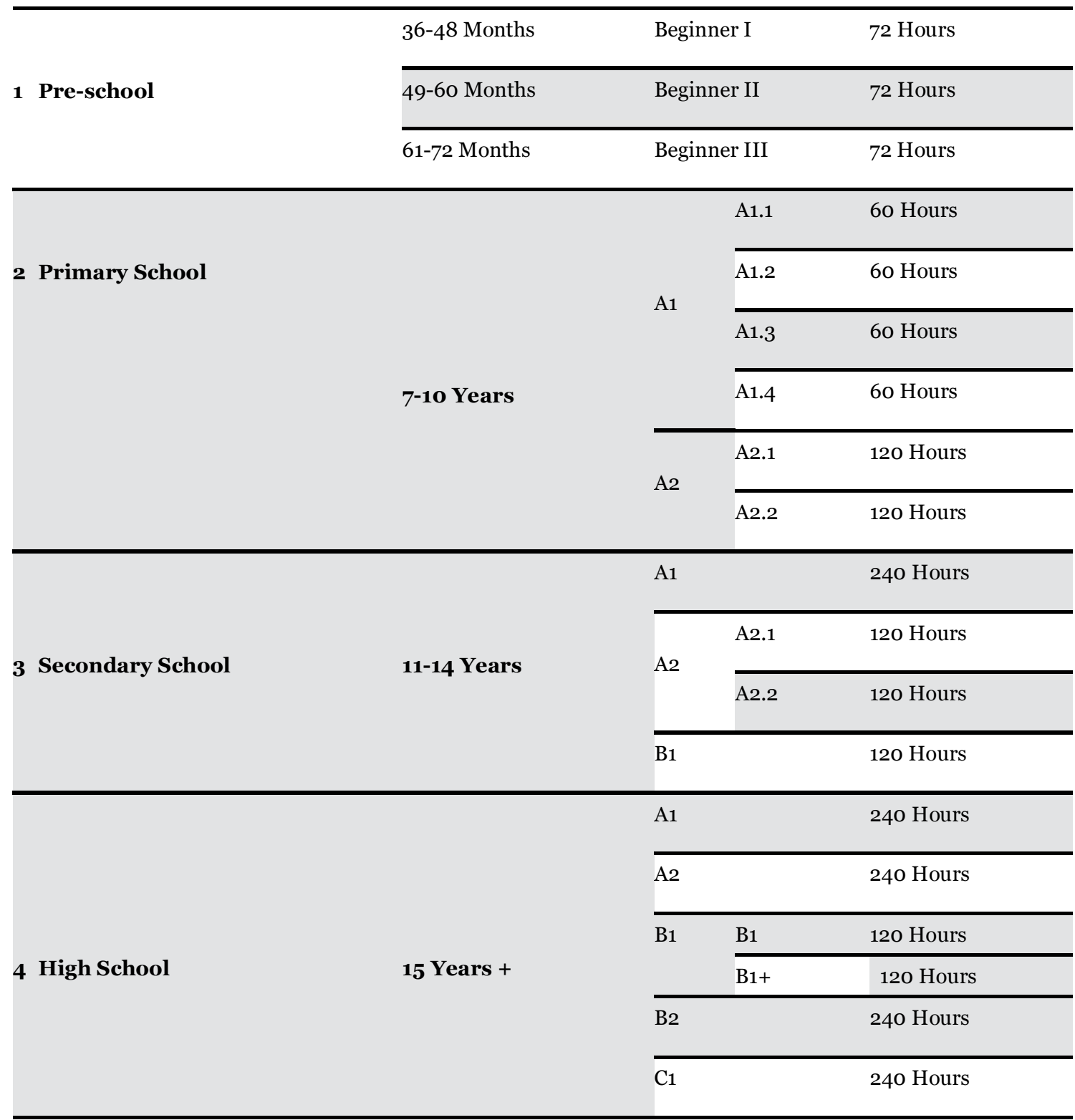

(TYDÖP, 2020, p. 26)

When Table 1 is analyzed, it is understood that it shows how many hours of education each language level covers in the domestic application of the curriculum and the language level learners are expected to reach according to the levels. The achievements related to listening, oral production, oral interaction, reading and writing skills are listed by considering the stages according to the language levels of the curriculum. The distribution of achievement for language levels is given in Table 2. 
Perceptions of the authors writing book sets for teaching Turkish as a foreign language on the process of writing a book / $\dot{\mathrm{I}}$. Gültekin (pp. 55-76)

Table 2. Distribution of Achievements by Language Skills and Levels

\begin{tabular}{|c|c|c|c|c|c|c|}
\hline \multirow{2}{*}{$\begin{array}{l}\text { Language } \\
\text { Skills }\end{array}$} & \multicolumn{5}{|c|}{ Language Levels } & \multirow[t]{2}{*}{$\begin{array}{l}\text { Total Number of Achievements by } \\
\text { Skills }\end{array}$} \\
\hline & A1 & A2 & B1 & B2 & C1 & \\
\hline Listening & 43 & 63 & 64 & 46 & 44 & 260 \\
\hline Oral Interaction & 32 & 40 & 46 & 43 & 36 & 197 \\
\hline Oral Production & 29 & 47 & 50 & 47 & 41 & 214 \\
\hline Reading & 48 & 65 & 70 & 58 & 50 & 291 \\
\hline Writing & 51 & 74 & 65 & 63 & 56 & 209 \\
\hline Total & 203 & $\mathbf{2 8 9}$ & 295 & $\mathbf{2 5 7}$ & 226 & 1271 \\
\hline
\end{tabular}

When Table 2 is analyzed, it is observed that the highest number of achievements in terms of language skills is in reading, and it is followed by the achievements in listening, oral production, writing and oral interaction respectively. In terms of language levels, it is possible to state that B1 is richer in terms of achievements compared to other levels. It is thought to be related to the function and content of the B1 level. Characterized as the threshold, B1 level can be considered the most important stage for the learner in the process of learning the target language. From this point of view, coursebooks to be prepared are expected to realize the achievements envisaged by the curriculum. Achievements were distributed to the determined themes at all levels of formal education; for this purpose, syllabuses for levels were created in the Curriculum. Therefore, the book author can create themes by following his/her syllabus. The mentioned point is revealed in Table 3 .

Table 3. An Example for a Syllabus Table Presented in the Curriculum for Teaching Turkish as a Foreign Language

\begin{tabular}{|c|c|c|c|c|}
\hline \multicolumn{5}{|l|}{ A1-11 YEARS } \\
\hline \multicolumn{5}{|l|}{ 5. Theme: My City } \\
\hline \multirow[b]{2}{*}{ Listening/watching } & \multicolumn{2}{|l|}{ Speaking } & \multirow[b]{2}{*}{ Reading } & \multirow[b]{2}{*}{ Writing } \\
\hline & Oral interaction & $\begin{array}{l}\text { Oral } \\
\text { Produ } \\
\text { ction }\end{array}$ & & \\
\hline $\begin{array}{l}\text { Selects basic } \\
\text { information about } \\
\text { transportation and } \\
\text { means of } \\
\text { transportation. } \\
\text { Recognizes simple } \\
\text { expressions containing } \\
\text { directions and address } \\
\text { descriptions. } \\
\text { Recognizes simple } \\
\text { expressions for } \\
\text { location. } \\
\text { Identifies simple } \\
\text { messages in a phone } \\
\text { conversation. }\end{array}$ & $\begin{array}{l}\text { Establishes simple } \\
\text { dialogues about } \\
\text { directions and } \\
\text { addresses. } \\
\text { Uses basic question } \\
\text { statements in her/his } \\
\text { speeches. } \\
\text { Uses basic } \\
\text { communication patterns } \\
\text { in audio or video } \\
\text { conversations. } \\
\text { Establishes dialogues } \\
\text { including requests for } \\
\text { help/permission/reques } \\
\text { ts/apologies. }\end{array}$ & $\begin{array}{l}\text { Makes a } \\
\text { simple } \\
\text { present } \\
\text { ation } \\
\text { support } \\
\text { ed by } \\
\text { visuals } \\
\text { on } \\
\text { familiar } \\
\text { topics. } \\
\text { Describ } \\
\text { es an } \\
\text { event in } \\
\text { simple } \\
\text { terms } \\
\text { accordi }\end{array}$ & $\begin{array}{l}\text { Selects basic } \\
\text { information about } \\
\text { transportation and } \\
\text { means of } \\
\text { transportation. } \\
\text { Understands simple } \\
\text { text containing } \\
\text { directions and address } \\
\text { descriptions. } \\
\text { Recognizes signs and } \\
\text { symbols that contain } \\
\text { information, } \\
\text { directions and } \\
\text { warnings that are } \\
\text { frequently }\end{array}$ & $\begin{array}{l}\text { Writes simple } \\
\text { sentences based on } \\
\text { images. } \\
\text { Writes simple texts } \\
\text { with directions and } \\
\text { addresses. } \\
\text { Uses simple } \\
\text { expressions of } \\
\text { location in her/his } \\
\text { writings. } \\
\text { Prepares texts such } \\
\text { as posters, tickets, } \\
\text { brochures, } \\
\text { announcements, } \\
\text { advertisements. }\end{array}$ \\
\hline
\end{tabular}




\begin{tabular}{|c|c|c|c|c|}
\hline $\begin{array}{l}\text { Identifies simple } \\
\text { phrases in a telephone } \\
\text { conversation. } \\
\text { Selects the } \\
\text { information s/he } \\
\text { needs from } \\
\text { audio/video messages } \\
\text { (announcements etc.). } \\
\text { Recognizes } \\
\text { expressions containing } \\
\text { request for } \\
\text { help/permission/requ } \\
\text { est/apology. } \\
\text { Recognizes the names } \\
\text { of places in her/his } \\
\text { environment. }\end{array}$ & $\begin{array}{l}\text { Asks and answers } \\
\text { questions during the } \\
\text { conversation. }\end{array}$ & $\begin{array}{l}\text { ng to } \\
\text { the } \\
\text { order in } \\
\text { which it } \\
\text { occurre } \\
\text { d. } \\
\text { Tells } \\
\text { basic } \\
\text { informa } \\
\text { tion in } \\
\text { texts } \\
\text { such as } \\
\text { posters. }\end{array}$ & $\begin{array}{l}\text { encountered in daily } \\
\text { life. } \\
\text { Selects the } \\
\text { information s/he } \\
\text { needs from visuals } \\
\text { such as maps, } \\
\text { sketches, graphs, } \\
\text { tables, and timelines. } \\
\text { Selects the } \\
\text { information s/he } \\
\text { needs from texts such } \\
\text { as posters, tickets, } \\
\text { brochures, } \\
\text { announcements and } \\
\text { advertisements. } \\
\text { Determines the order } \\
\text { of occurrence of events } \\
\text { in simple texts. } \\
\text { Recognizes } \\
\text { expressions containing } \\
\text { request for } \\
\text { help/permission/requ } \\
\text { est/apology. }\end{array}$ & $\begin{array}{l}\text { Uses the expressions } \\
\text { of request for } \\
\text { help/permission/req } \\
\text { uest/apology in } \\
\text { her/his writings. }\end{array}$ \\
\hline
\end{tabular}

Communicative Functions, Language Structures, Language Expressions and Vocabulary

\begin{tabular}{|c|c|c|c|c|}
\hline Communicative & & \multicolumn{3}{|c|}{ Language Expressions and Vocabulary } \\
\hline $\begin{array}{l}\text { *Asking-giving } \\
\text { information about } \\
\text { place-location } \\
\text { *Asking and giving } \\
\text { information about } \\
\text { places-directions and } \\
\text { addresses } \\
\text { *Asking and giving } \\
\text { information about } \\
\text { transportation and } \\
\text { means of } \\
\text { transportation } \\
\text { *Asking and giving } \\
\text { information about } \\
\text { the place/place } \\
\text { *Communicating } \\
\text { with audio/video } \\
\text { tools } \\
\text { *Using courtesy } \\
\text { expressions } \\
\text { - } \\
\text { Thanking/Respondin } \\
\text { g to thanks } \\
\text { *Putting into order } \\
\text { *Pointing }\end{array}$ & $\begin{array}{l}\text { *To... } \\
\text { *From... } \\
\text { to... } \\
\text { *In/on/at... } \\
\text { *Adverbs } \\
\text { (down, up, } \\
\text { forward, } \\
\text { backward, } \\
\text { in, out) } \\
\text { *by } \\
\text { (prepositio } \\
\text { n for } \\
\text { vehicles) } \\
\text { *In/on/at } \\
\text { *Where? } \\
\text { (here- } \\
\text { there) } \\
\text { *before/ } \\
\text { after/then } \\
\text { *Question } \\
\text { statements } \\
\text { (To where? } \\
\text { Where? } \\
\text { From } \\
\text { where? } \\
\text { With what? } \\
\text { Which, } \\
\text { How? } \\
\text { When? } \\
\text { What } \\
\text { time?) }\end{array}$ & \multicolumn{2}{|c|}{$\begin{array}{l}\text {-Excuse me, where is the... ? } \\
\text {-Walk from... to .... } \\
\text { Turn right/left. ..., opposite of... . } \\
\text {-I don't understand, could you } \\
\text { please repeat? } \\
\text { - ..... } \\
\text {-Thank you. } \\
\text {-You're welcome. } \\
\text { *** } \\
\text { By what ? (... by ...) } \\
\text { Where are you going? / -I'm going } \\
\text { to... . } \\
\text { - What are you going by? } \\
\text { / -I'm going by bus/ train/ } \\
\text { bicycle/ taxi/ plane/ on foot. } \\
\text { *** } \\
\text { Which child? } \\
\text { The child on the bus. } \\
\text { *** } \\
\text {-Hello, this is Ali, who am I talking } \\
\text { to? } \\
\text {-Hello, I am Hasan. How can I } \\
\text { help you? } \\
\text { - ... } \\
\text { *** } \\
\text { Note: In this theme, it is requested } \\
\text { to give directions on a phone call. }\end{array}$} & $\begin{array}{l}\text { Transport vehicles: } \\
\text { bus, bicycle, plane, train, taxi, } \\
\text { subway, tram, ship... } \\
\text { Basic verbs: } \\
\text { To get off, to get on, to ride, to go, } \\
\text { to turn back, to walk, to run, to } \\
\text { describe (address etc.) ... } \\
\text { Location and Direction Phrases: } \\
\text { opposite, in front of } \\
\text { behind/right/left- } \\
\text { in, outside, in the middle, next to } \\
\text {... } \\
\text { street, avenue, sidewalk, sign } \\
\text { board, traffic lights, stop, } \\
\text { pedestrian crossing, overpass, } \\
\text { underpass ... }\end{array}$ \\
\hline $\begin{array}{l}\text { Rumel } \\
\text { Osmanağ }\end{array}$ & $\begin{array}{r}\text { hallesi, Mürv } \\
\text { diköy - İSTAI } \\
\text { e-post } \\
+90505795\end{array}$ & $\begin{array}{r}\text { Adres } \\
\text { assttrmaları Dergisi } \\
\text { çeği Sokak, No:14/8 } \\
\text { L/ TÜRKiYE } 34714 \\
\text { itor@rumelide.com } \\
\text {, +90 } 216773 \text { o } 616\end{array}$ & $\begin{array}{l}\text { Address } \\
\text { RumeliDE Journal of } \\
\text { Osmanağa Mahallesi, } \\
\text { Kadıköy - ISTANBUL } \\
\text { e-mail: editor@rume } \\
\text { phone: +90 } 5057958\end{array}$ & $\begin{array}{l}\text { Inguage and Literature Studies } \\
\text { urver Çiçeği Sokak, No:14/8 } \\
\text { rURKEY } 34714 \\
\text { le.com, } \\
24,+90216773 \text { o } 616\end{array}$ \\
\hline
\end{tabular}




\begin{tabular}{l|l|l}
\hline & & The following phrases can also be \\
& used in this phone call. & \\
& *Phone call (address directions) & \\
& *Basic phrases used on the phone & \\
(Are you available? & Excuse me? Can I speak to...? I'm & \\
& bothering, sorry, I'll call \\
& back/later. & \\
\hline
\end{tabular}

(TYDÖP, 2020, p. 288-289)

As seen in Table 3, the 5th theme of A1 level at secondary school is My City. In this theme, after the achievements to be given for the skills are specified, the language functions to be acquired by the student in the theme, the language structures corresponding to these language functions, and the vocabulary examples represented by the theme are shown. Thus, the coursebook author shall create her/his theme within the determined limits.

The Curriculum for Teaching Turkish as a Foreign Language also provides information on how users can benefit from the Curriculum. This information is also a guide for authors who prepare coursebooks. The recommendations in the curriculum are as follows (TYDÖP, 2020, p. 36-38):

- The achievements should be realized within the framework of the principles of spirality and succession specified in the themes.

- Themes and achievements should be dealt with on the basis of needs and functions, and a line that progresses from usage to rule should be followed especially in grammar rules.

- Activities and practices aimed at presenting basic language skills in a spiral structure that support each other should be included.

- Learning Turkish should not be limited to in-class activities, social activities and tasks outside the classroom should be designed, and this process should be followed by teachers and families themselves.

- Learning strategies should be developed to carry the language teaching process outside classroom, and for this purpose, learners should be given tasks that they can perform individually outside the classroom.

- All kinds of written or oral production in Turkish at all ages and levels should be appreciated and encouraged, and learners should be motivated towards the target language.

- Entertaining pair/group activities such as games, songs and drama should be used for in-class and out-of-class activities.

- Assessment and evaluation tools should be structured in accordance with the age and proficiency level of learners.

- Assessment and evaluation tools allowing the evaluation of the process along with the result should be used.

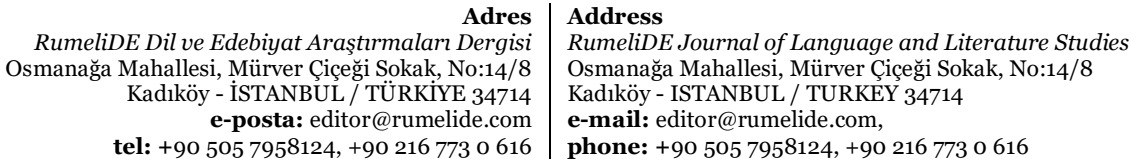

RumeliDE Dil ve Edebiyat Araştırmaları Dergis adï̈y - IST el: +90 $5057958124,+902167730616$ 
- Local and individual differences should be taken into account during the practice phase.

- From the beginning to the end of the language teaching and learning process, the realization of in-class and out-of-class communication in Turkish should be paid attention.

- Teaching materials and activities should be structured in standard Turkish.

- The features of all cultural values carried by language that overlap with the target language and culture should be highlighted, and activities and practices ensuring intercultural communication should be included.

- Grammar topics should be presented in a way that supports language skills.

- The activities and materials to be used in the language teaching process should be arranged by taking the language functions that emerge in the contexts of the personal space, public space, professional field and educational field specified in the curriculum into account.

- It should not be forgotten that the basic function of language is to communicate, and it should not be inconvenient to give basic communication patterns that are frequently used in daily life (such as "Can you help me? Please repeat." etc.).

- In teaching Turkish as a foreign language, grammatical structures and suffixes should be provided through a function-centered approach, not at the level of providing knowledge.

Considering the items listed for practitioners and users, it is understood that communication-oriented teaching of Turkish is aimed and what needs to be done in this regard is expressed. Considering the mentioned points, it can be stated that the functional use of the Curriculum for Teaching Turkish as a Foreign Language shall be provided through coursebooks.

While some of the book sets for teaching Turkish as a foreign language consist of coursebooks and workbooks suitable for levels, some of them consist of coursebooks, workbooks and teacher's guidebooks. A workbook is a course material that includes additional activities that enable learners to reinforce the content in the coursebook. On the other hand, a teacher's guidebook can be defined as a kind of guidebook that shows the stages that the teacher shall follow during the course process. There is not any information about the the qualities of the workbook and teacher's guide book prepared for teaching Turkish as a foreign language. However, it can be stated that the qualities of the workbook and teacher's guidebook prepared for native speakers can also be taken into account in teaching Turkish as a foreign language (MEB, Journal of Notifications No. 2652-2663, 2012).

The Turkish Maarif Foundation is the first institution to start the process of preparing the coursebook by considering the Curriculum for Teaching Turkish as a Foreign Language (2020). It continues to write coursebooks with its team of authors and editors for all levels and language levels, from pre-school to high school. The main point of the research is this issue of of being the first. In the study, it is aimed to reveal the perceptions of the authors who continue the coursebook writing process based on the Curriculum for Teaching Turkish as a Foreign Language on the process of writing book.

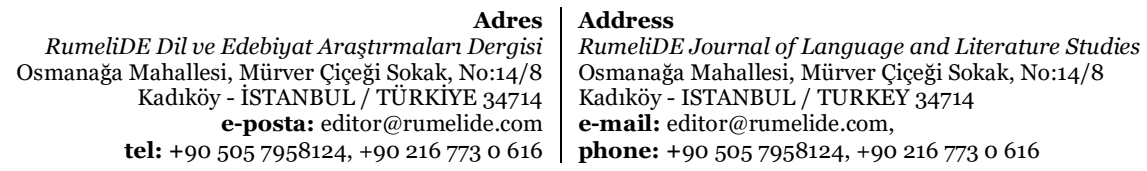


Perceptions of the authors writing book sets for teaching Turkish as a foreign language on the process of writing a book / $\dot{\mathrm{I}}$. Gültekin (pp. 55-76)

\section{Method}

Phenomenology was used in this research which aims to determine the perceptions of the authors who prepare coursebooks for the teaching of Turkish as a foreign language. In phenomenology, which is an empirical study method focusing on the experiences of people about phenomena and the differences in their perceptions, the ways in which phenomena are defined differ due to individual differences. According to Ylldırım and Şimşek (2008), phenomenology does not reveal precise and generalizable results due to the nature of qualitative research but it offers experiences that shall provide results helping to recognize and understand a phenomenon better.

\section{Study group}

In phenomenological studies, data sources are individuals or groups that experience the phenomenon the research focuses on and can express or reflect this phenomenon (Ylldırım-Şimşek 2008). The study group of this research consists of 22 authors who participated in the book writing process of the Turkish Maarif Foundation, which is the first group of authors suitable for the Curriculum for Teaching Turkish as a Foreign Language (2020). Easy accessibility and voluntariness were taken as basis in determining the study group. Personal information of the participants in the study group is given in Table 4 .

Table 4. Personal Information of the Participants in the Study Group

\begin{tabular}{|c|c|c|c|}
\hline Gender & Graduation & Department & $\begin{array}{l}\text { Level of the } \\
\text { Book }\end{array}$ \\
\hline Female & $\begin{array}{l}\text { Marmara University and Anadolu } \\
\text { University }\end{array}$ & $\begin{array}{l}\text { Turkish Language and Literature- } \\
\text { Sufism and Kalam }\end{array}$ & Pre-school \\
\hline Female & Yıldız Technical University & English Teaching & Pre-school \\
\hline Female & Boğaziçi University & $\begin{array}{l}\text { Psychological Counseling and } \\
\text { Guidance }\end{array}$ & Pre-school \\
\hline Female & Yıldız Technical University & Pre-school teaching & Pre-school \\
\hline Male & Bolu Abant İzzet Baysal University & Classroom teaching & Primary school \\
\hline Female & İstanbul University & Turkish Language and Literature & Primary school \\
\hline Female & Hacettepe University & Turkish Teaching & Primary school \\
\hline Female & Gazi University & Turkish Teaching & Primary school \\
\hline Female & Karadeniz Technical University & Turkish Teaching & Secondary school \\
\hline Female & Eötvös Lorand University & Intercultural Linguistics & Secondary school \\
\hline Male & Kırıkkale University & Turkish Teaching & Secondary school \\
\hline Male & Tokat Gaziosmanpaşa University & Turkish Language and Literature & Secondary school \\
\hline Male & Kurklareli University & Turkish Language and Literature & Secondary school \\
\hline Male & Mersin University & Turkish Teaching & Secondary school \\
\hline Male & Hacettepe University & Classroom teaching & Secondary school \\
\hline Male & Çanakkale Onsekiz Mart University & Turkish Language and Literature & High school \\
\hline Female & İstanbul University & Turkish Language and Literature & High school \\
\hline Female & Necmettin Erbakan University & Turkish Language and Literature & High school \\
\hline Female & $\begin{array}{l}\text { TOBB University of Economics and } \\
\text { Technology }\end{array}$ & Turkish Language and Literature & High school \\
\hline & $\begin{array}{r}\text { Adres } \\
\text { RumeliDE Dil ve Edebiyat Araştrrmaları Dergisi } \\
\text { Osmanağa Mahallesi, Mürver Ciçĕgi Sokak, No:14/8 } \\
\text { Kadıköy - İSTANBUL / TÜRKIYE } 34714 \\
\text { e-posta: editor@rumelide.com } \\
\text { tel: +90 505 7958124, +90 216 773 o } 616\end{array}$ & \multicolumn{2}{|c|}{\begin{tabular}{l|l} 
s & Address \\
$i$ & RumeliDE Journal of Language and Literature Studies \\
3 & Osmanağa Mahallesi, Mürver Ciceği Sokak, No:14/8 \\
4 & Kadıköy - ISTANBUL/ TURKEY 34714 \\
a-mail: editor@rumelide.com, \\
phone: +90 505 7958124, +90 216773 o 616
\end{tabular}} \\
\hline
\end{tabular}




\begin{tabular}{llll}
\hline Female & Eskişehir Osmangazi University & Comparative Literature & High school \\
\hline Male & Korkut Ata Kızllorda Public University & Turkish Language and Literature & High school \\
\hline Female & Marmara University & $\begin{array}{l}\text { Turkish Language and Literature } \\
\text { Teaching }\end{array}$ & High school \\
\hline
\end{tabular}

As can be seen in Table 4, 14 of the participants are female and 8 are male. The participants also stated before the interview that they had experience in teaching Turkish as a foreign language.

\section{Data collection}

A semi-structured interview form was used to collect data in the research. The questions in the interview form were first prepared by the researcher and evaluated by three field experts. While a total of five (5) questions, on which the experts expressed a positive consensus, were included in the interview form, two (2) questions focusing on similar issues in terms of content were excluded from the interview form.

A preliminary application was conducted for the interview form which was evaluated in terms of its content and suitability for the aim of the research. Interview questions were first applied to two authors who were not included in the study group. In line with the data obtained, the interview form was revised again with the field experts and the form was finalized. The questions included in the interview form are as follows:

1. What are the principles you consider in the process of preparing a coursebook for teaching Turkish as a foreign language? Can you explain?

2. When you consider the language teaching levels, what can you say about the difficult and easy aspects of the coursebook writing process?

3. In your opinion, what are the characteristics that the texts in the coursebook should have? Can you explain?

4. Can you talk about the aspects you paid attention to while preparing the activities in the coursebook?

5. In your opinion, should the book sets prepared for foreigners consist of a coursebook, a workbook and a teacher's guidebook, or should it be just a coursebook? Can you explain your opinions with reasons?

The data based on the questions in the semi-structured interview form were collected by the researcher as a result of the interviews with the participants. Interviews were held at the Turkish Maarif Foundation. They lasted between 20 and 30 minutes on average. The collection of research data took 12 days.

\section{Data analysis}

Data of this study were collected in accordance with the phenomenology method and content analysis was used in the analysis of the data. A field expert and researcher worked together during the analysis process. Since this type of research is aimed at revealing experiences and meanings, in the content analysis, it is aimed to conceptualize the data and to reveal the themes which can define the phenomenon

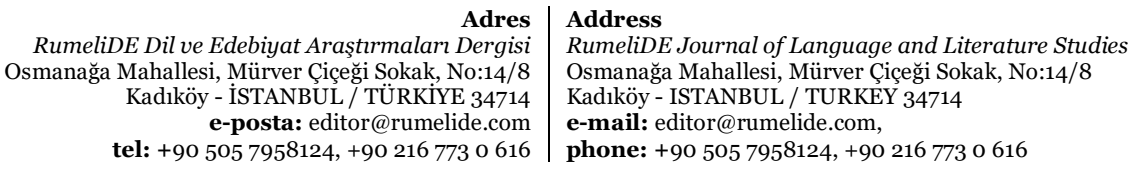


Perceptions of the authors writing book sets for teaching Turkish as a foreign language on the process of writing a book / $\dot{\mathrm{I}}$. Gültekin (pp. 55-76)

(Ylldırım-Şimşek 2008). First of all, the acquired data were re-analyzed, and then categorized; and finally, the meaning categories in the final text were analyzed. After categorizing, comparisons were made between categories. In this way, categories concluded by the expert and the researcher were finalized. The main meanings were tagged, the concepts were grouped and categorized, and the categories were named. After the categories were determined, tables were created and the tables were enriched with sentences that could be examples of the categories. Codes were given to 22 authors who participated in the study regardless of their names and genders by taking the level at which they write coursebooks into account. This situation is presented in Table 5 .

Table 5 . The Codes Given to the Participants in the Study Group by Level

\begin{tabular}{|c|c|}
\hline Level of Authorship & Participant Code \\
\hline Pre-school & OÖK1, OÖK2, OÖK3, OÖ4 \\
\hline Primary School & İLK1, İLK2, İLK3, İLK4 \\
\hline Secondary School & $\mathrm{OK}_{1}, \mathrm{OK}_{2}, \mathrm{OK}_{3}, \mathrm{OK}_{4}, \mathrm{OK}_{5}, \mathrm{OK}_{6}, \mathrm{OK}_{7}$ \\
\hline High School & LK1, LK2, LK 3, LK4, LK5, LK6, LK7 \\
\hline
\end{tabular}

When Table 5 is analyzed, it is understood that 4 authors from pre-school, 4 authors from primary school, 7 authors from secondary school, and 7 authors from high school levels participated in the study.

\section{Findings and interpretation}

As a result of the answers given by the participants to the questions in the interview form, the following findings were reached in the study.

Table 6. Principles to be Considered During the Process of Preparing the Coursebook in Teaching Turkish as a Foreign Language

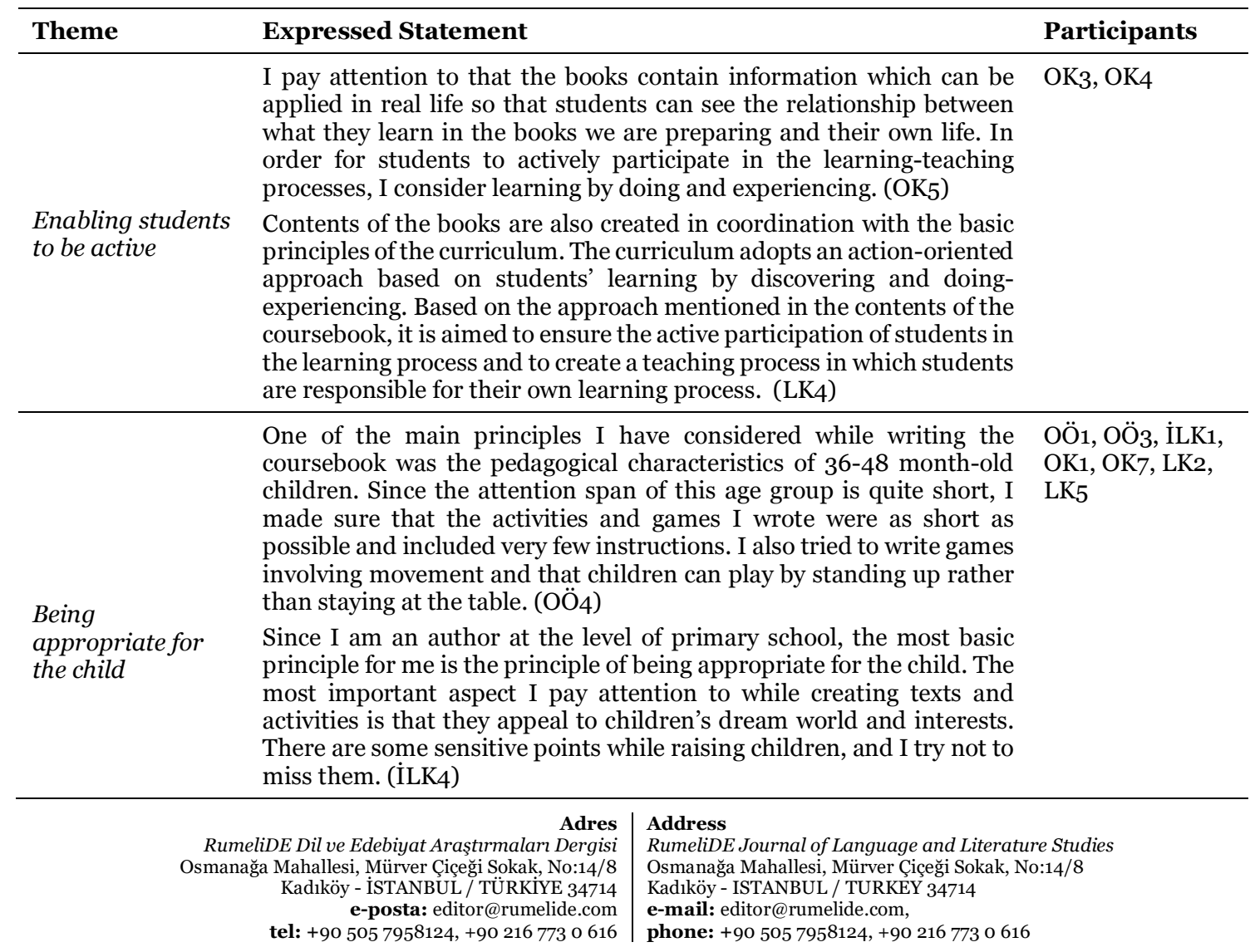




\begin{tabular}{|c|c|c|}
\hline \multirow[b]{2}{*}{ Progressiveness } & $\begin{array}{l}\text { I pay attention to the fact that the topics and activities in the books are } \\
\text { presented in a progressive order as being from easy to difficult and } \\
\text { from known to unknown in a meaningful whole, and that the activities } \\
\text { shall facilitate further learning and form a basis for them. (OÖ2) }\end{array}$ & $\mathrm{LK}_{3}$ \\
\hline & $\begin{array}{l}\text { The spiral programming approach is used in the coursebooks. The } \\
\text { spiral approach contributes to the child to carry each new proficiency } \\
\text { to the next proficiency level. Books are progressive. This } \\
\text { progressiveness is from the known to the unknown, from the simple to } \\
\text { the complex, from the easy to the difficult, from the general to the } \\
\text { specific, and from the concrete to the abstract. Language structures } \\
\text { and vocabulary acquired in one unit are repeated in the next units. } \\
\text { (ILK2) }\end{array}$ & \\
\hline \multirow{3}{*}{$\begin{array}{l}\text { Planning of } \\
\text { Language } \\
\text { Teaching }\end{array}$} & $\begin{array}{l}\text { First of all, the most important factor that I took into consideration was } \\
\text { to start this work by analyzing the curriculum in detail. Understanding } \\
\text { the logic of the achievements, determining which achievement can be } \\
\text { given more easily with which achievement, correctly determining the } \\
\text { language structures and vocabulary that should be given according to } \\
\text { the achievement, and finally making the unit's syllabus division by } \\
\text { taking these issues into account are the issues related to the } \\
\text { curriculum. (OK2) }\end{array}$ & \multirow[t]{3}{*}{ İLK3, LK6, LK7 } \\
\hline & $\begin{array}{l}\text { I am trying to construct the coursebook based on the question that } \\
\text { "How can we develop Turkish communication skills of students?" } \\
\text { Within this framework, I try to consider the curriculum, the } \\
\text { achievements in the curriculum, the communicative functions } \\
\text { specified in the curriculum, and the grammar structures and } \\
\text { vocabulary items that reflect these functions. (OK6) }\end{array}$ & \\
\hline & $\begin{array}{l}\text { All of the content of the coursebook should be in accordance with the } \\
\text { syllabuses in the curriculum, the achievements of the four skills } \\
\text { determined in the syllabuses and the issue of theme. Because the spiral } \\
\text { structure of the curriculum -from the first to the last level- constitutes } \\
\text { a whole. As a matter of fact, the content to be created or compiled in } \\
\text { the writing of the coursebook should also be compatible with the } \\
\text { achievements; activities and visuals designed based on the content } \\
\text { should also be produced in a way that shall serve to realize the } \\
\text { achievements. (LK1) }\end{array}$ & \\
\hline
\end{tabular}

In Table 6, the findings acquired as a result of the question "What are the principles you consider in the process of preparing a coursebook for teaching Turkish as a foreign language? Can you explain?" are presented. The findings acquired from the participants were classified under 4 themes as being enabling students to be active, being appropriate for the child, progressiveness, and planning of language teaching. Participants gathered mostly in the theme of being appropriate for the child. Since the target audience is the student, it is understood that while preparing the coursebook, attention is paid to children's interests, developmental characteristics, and game-based activities. Six participants agreed on the theme of planning of language teaching. It was stated that they had planned the content of the book according to the achievements, themes and communicative functions in the curriculum. Other principles stated by the participants are progressiveness and enabling students to be active in the process.

In the scope of the research, the answer of the question "When you consider the language teaching levels, what can you say about the difficult and easy aspects of the coursebook writing process?" was sought. In accordance with the nature of the question, the findings obtained from the participants were presented under two categories as being difficult aspects and easy aspects.

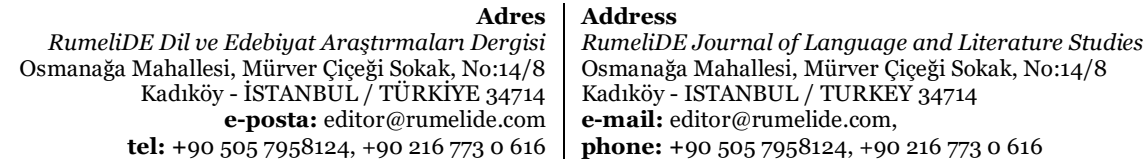


Perceptions of the authors writing book sets for teaching Turkish as a foreign language on the process of writing a book / $\dot{\mathrm{I}}$. Gültekin (pp. 55-76)

Table 7. Coursebook Writing Process By Levels of Language Teaching

\begin{tabular}{|c|c|c|c|}
\hline Theme & & Expressed Statement & Participants \\
\hline \multirow{5}{*}{$\begin{array}{l}\text { Difficult } \\
\text { aspects }\end{array}$} & \multirow{3}{*}{$\begin{array}{l}\text { Language } \\
\text { Teaching at the } \\
\text { Beginner Level }\end{array}$} & $\begin{array}{l}\text { Writing a book at the preschool level can be a } \\
\text { challenging process as it requires being very careful and } \\
\text { selective in terms of limited language structure, } \\
\text { expression and the use of words. In addition, since it is } \\
\text { almost impossible to find original texts suitable for this } \\
\text { level, writing new texts poses a challenge in terms of the } \\
\text { process. (OÖ2) }\end{array}$ & $\begin{array}{l}\mathrm{OÖ}_{3}, \mathrm{OÖ}_{4}, \text { İLK1, } \\
\text { İLK3, İLK4, OK1, } \\
\text { OK4, OK6, OK7, } \\
\text { LK} 3, \text { LK4, LK6, }\end{array}$ \\
\hline & & $\begin{array}{l}\text { Assuming that they have never encountered the target } \\
\text { language before, writing a book for pre-school children } \\
\text { aged between } 36-48 \text { months and for primary school A1.1 } \\
\text { level students can be considered a very difficult attempt. } \\
\text { (İLK2) }\end{array}$ & \\
\hline & & $\begin{array}{l}\text { As A1 and A2 levels offer a more limited area compared } \\
\text { to other levels, it seems more difficult to prepare } \\
\text { content at these levels. Although it seems that the } \\
\text { content can be prepared more easily due to the } \\
\text { accumulation of knowledge in students as they reach } \\
\text { higher levels, actually, this is not the case. Because, it is } \\
\text { necessary to either find authentic texts or write required } \\
\text { texts for the teaching of related language structures } \\
\text { along with sample topics. This is not an easy task either. } \\
\text { In addition, author may start giving same activities and } \\
\text { games after a while. Therefore, there is not any easy } \\
\text { aspect of the process but the difficult aspects are quite a } \\
\text { lot. (LK1) }\end{array}$ & \\
\hline & \multirow[t]{2}{*}{$\begin{array}{l}\text { Language } \\
\text { Teaching at the } \\
\text { Intermediate and } \\
\text { Advanced Levels }\end{array}$} & $\begin{array}{l}\text { Since B1 and advanced levels are especially high school } \\
\text { level, achievements are extremely intense and complex. } \\
\text { When we consider that even some Turks cannot speak } \\
\text { Turkish at B2 and C1 levels, I can express how difficult } \\
\text { it is to write a Turkish coursebook at these levels. In } \\
\text { short, I can say that A1 and A2 levels are easy, while } \\
\text { other levels are difficult in terms of producing activities } \\
\text { suitable for the learning achievements. (LK5) }\end{array}$ & \multirow[t]{2}{*}{$\mathrm{OK}_{3}, \mathrm{LK}_{2}, \mathrm{LK}_{7}$} \\
\hline & & $\begin{array}{l}\text { Since the increase in the number and intensity of } \\
\text { achievements at } \mathrm{B} 1, \mathrm{~B} 1+\text { and } \mathrm{B} 2 \text { levels requires the } \\
\text { preparation of much more functional and creative } \\
\text { activities addressing more than one achievement at the } \\
\text { same time, it is sometimes difficult to write activities at } \\
\text { levels such as B1 and B1+. (LK2) }\end{array}$ & \\
\hline & \multirow{2}{*}{$\begin{array}{l}\text { Existence of the } \\
\text { Curriculum for } \\
\text { Teaching Turkish } \\
\text { as a Foreign } \\
\text { Language }\end{array}$} & $\begin{array}{l}\text { The greatest easy aspect is to have a curriculum in } \\
\text { front of us which is like a guide or a map for us. (OK2) }\end{array}$ & \multirow[t]{2}{*}{ İLK3 } \\
\hline & & $\begin{array}{l}\text { The fact that which acquisitions, communicative } \\
\text { functions, grammatical structures and vocabulary } \\
\text { items shall be given in which theme has been } \\
\text { determined provides a very important framework for } \\
\text { the coursebook author. (OK6) }\end{array}$ & \\
\hline & \multirow{2}{*}{$\begin{array}{l}\text { Language } \\
\text { Teaching at the } \\
\text { Beginner Level }\end{array}$} & $\begin{array}{l}\text { Each language teaching level has easy as well as } \\
\text { difficult aspects. The presence of a narrow framework } \\
\text { in the texts, activities and materials prepared for } \\
\text { language teaching at the basic level, in a way, makes it } \\
\text { easier for me. }\left(\mathrm{OK}_{5}\right)\end{array}$ & \multirow[t]{2}{*}{$\mathrm{OO}_{2}, \mathrm{OK}_{3}$} \\
\hline $\begin{array}{l}\text { Easy } \\
\text { aspects }\end{array}$ & & $\begin{array}{l}\text { I think writing a Turkish coursebook at A1 and A2 } \\
\text { levels is easier than writing at other levels. Because } \\
\text { there are basic achievements at these levels, and less } \\
\text { cognitive load occurs to produce activities meeting the } \\
\text { achievements. (LK5) }\end{array}$ & \\
\hline
\end{tabular}

Language Since B1 and advanced levels are especially high school Teaching at the level, achievements are extremely intense and complex. Intermediate and When we consider that even some Turks cannot speak it is to write a Turkish coursebook at these levels. In short, I can say that A1 and A2 levels are easy, while Since the increase in the number and intensity of achievements at $\mathrm{B} 1, \mathrm{~B} 1+$ and $\mathrm{B} 2$ levels requires the privities addressing more than one same time, it is sometimes difficult to write activities at

Existence of the Curriculum for as a Foreign Language

Adres

RumeliDE Dil ve Edebiyat Araştırmaları Dergisi Osmanağa Mahallesi, Mürver Çiçeği Sokak, No:14/8 Kadıköy - ISTANBUL / TÜRKIYE 34714 e-posta: editor@rumelide.com tel: +90 $5057958124,+902167730616$
Address

RumeliDE Journal of Language and Literature Studies Osmană̆a Mahallesi, Mürver Çiçeği Sokak, No:14/8

Kadıköy - ISTANBUL / TURKEY 34714

e-mail: editor@rumelide.com,

phone: +90 5057958124 , +90 2167730616 


\begin{tabular}{ll}
\hline & Having a spiral approach at the levels, in other words, OÖ3, OK1, OK7, \\
giving a previously provided achievement, language $\mathrm{LK}_{3}, \mathrm{LK} 4, \mathrm{LK} 6$ \\
expression or language structures at the next levels and \\
being a little more comfortable while creating text are \\
easy aspects. (OK4) \\
I mean, when the levels of A1.2 and A1.3 are reached in \\
pre-school at the age of 49-60 months and in primary \\
school-in accordance with the Release of Responsibility \\
Model-, convenience is provided in the teaching- \\
learning process by putting new language inputs on the \\
existing language inputs that students have \\
learned/acquired at previous levels. (ILK2) \\
At B1, B1+ and B2 language levels, the widening and \\
diversification of language structures, language \\
expressions and vocabulary makes text writing easier. \\
(LK2) \\
While I was writing these levels (A1-A2), I did not have (Ö̈4) \\
much difficulty because since I taught at least 40 classes \\
at these levels, there was a space in my mind about the \\
language usage areas and language structures suitable \\
for those areas. In addition, my active participation in \\
the writing process of the Curriculum for Teaching \\
Turkish as a Foreign Language was one of the biggest \\
factors which made this process easier. (LK7) \\
\hline Having experience
\end{tabular}

Table 7 is shaped by the themes of difficult aspects and easy aspects. The theme of difficulties is divided into two themes within itself as being beginner level, and intermediate and advanced levels. 15 participants stated that it is difficult to produce content and activities at the beginner level. 5 participants in the theme of intermediate and advanced levels stated that it is difficult to produce activities and content when levels progress. This table was shaped in accordance with the opinions of 20 people. With the opinions that "When I look at the difficulties, the biggest difficulty is the lack of time. Another is the problem of concentration when there is no opportunity to study for a long time, Being motivated again when I take a break due to external factors, The fact that the relationship between the activities, chapters or books in the set is interrupted when there is a break due to external factors, and the extra time I spend to construct this unity in my head" and that "In my opinion, the hardest part of the process is narrowing the arch between practice and theory", OK2 and OÖ1 stayed out of themes, respectively.

Another main theme of Table 7 is easy aspects. 9 participants stated that advanced language teaching is easier because it takes place in the form of a spiral structure. Having new language inputs in a progressive way at each level has facilitated activity and material design. 4 participants stated that the process of writing a book at the basic level is easier. This might be because of the fact that achievements at this level are simpler and the cognitive load and framework to be taught are less. Three participants were guided by the Curriculum while two participants managed the process more easily with their previous experiences. This table was prepared in line with the opinions of 18 participants. Participants with the code names ILLK1, ILLK4 and LK1 stated that the process of writing a book does not have any easy aspect. With the opinion that "In my personal experience, it was facilitating for me to imagine the applicability and effect of the process in terms of teachers, parents and students while writing an activity", OÖ1 stayed out of themes.

Opinions of the participants about the characteristics that the texts in the coursebook should have were also received. The acquired findings are presented in Table 8.

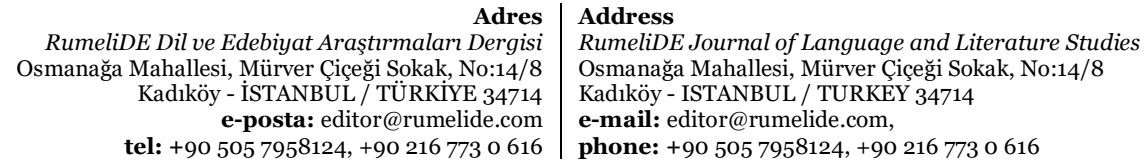

Adres
RumeliDE Dil ve Edebiyat Araştırmaları Dergisi tel: +90 $5057958124,+902167730616$ 
Perceptions of the authors writing book sets for teaching Turkish as a foreign language on the process of writing a book / $\dot{\mathrm{I}}$. Gültekin (pp. 55-76)

Table 8. Characteristics that the Texts in the Coursebook Should Have

\begin{tabular}{|c|c|c|}
\hline Theme & Expressed Statement & Participants \\
\hline \multirow{4}{*}{$\begin{array}{l}\text { Being Appropriate } \\
\text { for the Aim, } \\
\text { Achievement, Level, } \\
\text { Theme and Student }\end{array}$} & $\begin{array}{l}\text { The most important characteristics sought in the written texts are } \\
\text { that they are appropriate for the learning achievements and the } \\
\text { content of the unit. It is important that we use texts that do not } \\
\text { spoil the general structure of the book, that go in parallel with the } \\
\text { fiction, that usually include the characters created in the books, and } \\
\text { that include language structures, vocabulary in the unit and } \\
\text { predetermined language information for the unit. (ILK2) }\end{array}$ & \multirow[t]{4}{*}{$\begin{array}{l}\text { OÖ2, İLK1, İLK3, } \\
\mathrm{OK}_{3}, \mathrm{OK}_{5}, \mathrm{LK} 2 \text {, } \\
\text { LK4, LK7 }\end{array}$} \\
\hline & $\begin{array}{l}\text { Texts in the coursebook should be appropriate for the target } \\
\text { audience in terms of the subject and the way of processing. In } \\
\text { addition to being related to the theme, texts should also contain the } \\
\text { achievements and grammatical structures correctly. Texts should } \\
\text { not have divisive, discriminatory or violent characteristics. There } \\
\text { should not be any extreme expressions such as derogatory or } \\
\text { excessively glorifying expressions about individuals and } \\
\text { communities. (OK1) }\end{array}$ & \\
\hline & $\begin{array}{l}\text { First of all, the most distinctive characteristic that the texts in the } \\
\text { coursebook should have is that they must be suitable for the } \\
\text { achievements and communicative functions of the relevant unit. At } \\
\text { the same time, I think, everything related to the written subject } \\
\text { should not be attempted to be given, but what is sufficient for the } \\
\text { student should be given. Texts should be written in accordance } \\
\text { with the levels. (LK3) }\end{array}$ & \\
\hline & $\begin{array}{l}\text { Texts should be appropriate for achievements and communicative } \\
\text { functions, Texts should be appropriate for the subject of the theme, } \\
\text { Texts should be appropriate for the language level. Texts should } \\
\text { include the vocabulary and language structure of the relevant } \\
\text { theme. Texts should be interesting. Texts should be fluent. Texts } \\
\text { should be student oriented. (LK6) }\end{array}$ & \\
\hline $\begin{array}{l}\text { Original - Up-to- } \\
\text { date-Real }\end{array}$ & $\begin{array}{l}\text { It is important that texts are interesting and appeal to the interests } \\
\text { of the age group. Texts should be dynamic and talk about the recent } \\
\text { times, so the publications should always be updated. The author } \\
\text { should avoid using repetitive and similar texts. The author of the } \\
\text { book should be a good researcher; and like a miner, s/he should } \\
\text { discover what is hidden about his/her subject. At the same time, we } \\
\text { have to be original since we never use any authentic text at this } \\
\text { stage. (ILK4) }\end{array}$ & LK1 \\
\hline
\end{tabular}

I think that it should be simple and clear for younger age groups; depending on age groups, it should be internalized by either carrying story and fairy tale elements or by appealing to interests and needs, it should reflect the music of the language, and it should contain elements of rhyme as much as possible in order to be easily remembered. (OÖ1)

Being appropriate Texts should be appealing to the interests of students learning the target language. For example, it should be in a way that appeals to the world of primary and secondary school children and attracts their attention. For students at high school level, it should be appealing to their world. That is to say, we should consider the age and level of the target audience while writing texts. (OK4)

Cultural differences are definitely and absolutely indispensable in texts. Because teaching a language cannot be separated from culture. But it does not mean that we shall only give Turkish

The Relationship between Language and Culture culture. In addition to the construction of the education of Turkish culture, intercultural awareness should also be given to the child. (OK2)

The student should be given world knowledge through a reading or listening text. Turkish culture and other cultures should be introduced within the framework of sensitivities. (LK5)
RumeliDE Dil ve Edebiyat Araştırmaları Dergisi Osmanağa Mahallesi, Mürver Çiçeği Sokak, No:14/8 Kadıköy - ISTANBUL / TÜRKIYE 34714 e-posta: editor@rumelide.com tel: +90 $5057958124,+902167730616$
Address

RumeliDE Journal of Language and Literature Studies

Osmanağa Mahallesi, Mürver Çiçeği Sokak, No:14/8

Kadıköy - ISTANBUL / TURKEY 34714

e-mail: editor@rumelide.com,

phone: +90 505 7958124, +90 2167730616 
In Table 8, the findings acquired as a result of the question "In your opinion, what are the characteristics that the texts in the coursebook should have? Can you explain?" are presented. Themes created in line with the opinions of the participants are as follows: "Being Appropriate for the Aim, Achievement, Level, Theme and Student; Original - Up-to-date - Real; Being Appropriate for the Child; The Relationship between Language and Culture". The theme of "Being Appropriate for the Aim, Achievement, Level, Theme and Student" is the theme with the most opinions with 12 participants. As can be understood from here, it is stated that texts should primarily serve the aim while preparing the coursebook. It is a pre-condition that texts are appropriate for the theme, level and student in order to realize the achievements. In addition, it is understood that texts should be original, real and up-to-date and reflect the relationship between language and culture. The theme of being appropriate for the child was shaped through the opinions of 4 participants. Table 8 reflects the opinions of 8 participants. The participant given the code of OÖ4 stayed out of themes with the following answer: "I will not be able to provide an explanation for this question as there is no text at pre-school level."

The aspects to be considered in the activities while preparing the coursebook were questioned within the framework of the research. The acquired findings are presented in Table 9.

Table 9. The Aspects to be Considered While Preparing Activities

\begin{tabular}{|c|c|c|}
\hline Theme & Expressed Statement & Participants \\
\hline \multirow{4}{*}{$\begin{array}{l}\text { Achievement and } \\
\text { Functionality } \\
\text { Based }\end{array}$} & $\begin{array}{l}\text { First of all, the activities I prepare should meet all the targeted } \\
\text { achievements and functions of the Curriculum for Teaching Turkish as } \\
\text { a Foreign Language. For this aim, I am preparing activities based on the } \\
\text { achievement, I try not to include unnecessary activities and the activities } \\
\text { that do not meet the achievements of the level. (ILK3) }\end{array}$ & \multirow[t]{3}{*}{$\begin{array}{l}\text { OK7, İLK4, } \\
\text { LK6 }\end{array}$} \\
\hline & $\begin{array}{l}\text { I pay attention that the activities are appropriate for the achievements } \\
\text { and communicative functions in the curriculum. Additionally, I try to } \\
\text { prepare students for Turkish communication situations through } \\
\text { activities. I aim to create activities that shall contribute to students' } \\
\text { ability to understand and explain Turkish, based on the achievements } \\
\text { and communicative functions. (OK6) }\end{array}$ & \\
\hline & $\begin{array}{l}\text { I pay attention to whether the activities serve the achievements or not, } \\
\text { and if there are elements that do not serve the focus in an activity that I } \\
\text { have taken as an example or adapted, I amend or remove them. (LK1) }\end{array}$ & \\
\hline & $\begin{array}{l}\text { I pay attention to prepare activities which are in line with Bloom's } \\
\text { Taxonomy's steps of understand, remember and apply. (OK5) }\end{array}$ & \multirow[t]{2}{*}{ İLK2, LK4 } \\
\hline $\begin{array}{l}\text { Compliance with } \\
\text { the Steps of } \\
\text { Taxonomy }\end{array}$ & $\begin{array}{l}\text { While preparing our activities, we pay attention that our after reading } \\
\text { activities are in accordance with the "remember, understand, and apply" } \\
\text { steps of the revised Bloom's Taxonomy. (LK2) }\end{array}$ & \\
\hline \multirow[t]{3}{*}{ Target Audience } & $\begin{array}{l}\text { To ensure that the activity is appropriate for the age level of the children, } \\
\text { To ensure that the activity is fun, attractive and active, To try to design } \\
\text { the activity in a way that can be explained to children without using their } \\
\text { mother tongue. (OÖ3) }\end{array}$ & \multirow[t]{2}{*}{ OÖ4 } \\
\hline & $\begin{array}{l}\text { While preparing the activity, first of all, they are prepared according to } \\
\text { the children's developmental characteristics and related areas. (ILK1) }\end{array}$ & \\
\hline & $\begin{array}{l}\text { In pre-school age group, indirect teaching and implicit learning should } \\
\text { be targeted rather than direct teaching; for this reason, giving the target } \\
\text { language expressions to this age group with plenty of repetitions, and } \\
\text { games and activities in which entertainment and physical activities are } \\
\text { prioritized creates the starting point in activity planning. (OÖ2) }\end{array}$ & \multirow[t]{2}{*}{ OÖ1, OK4 } \\
\hline $\begin{array}{l}\text { Game and Practice } \\
\text { Based }\end{array}$ & $\begin{array}{l}\text { While preparing the activity, I make sure that it is in a style that shall } \\
\text { attract the attention of the students. I plan the activities in a way that } \\
\text { students will enjoy, play and learn through games, and use their reason, }\end{array}$ & \\
\hline
\end{tabular}

RumeliDE Dil ve Edebiyat Araştırmalar Dergis Osmanağa Mahallesi, Mürver Çiçeği Sokak, No:14/8 Kadıköy - ISTANBUL / TÜRKIYE 34714 e-posta: editor@rumelide.com tel: +90 $5057958124,+902167730616$
Address

RumeliDE Journal of Language and Literature Studies

Osmanağa Mahallesi, Mürver Çiçeği Sokak, No:14/8

Kadıköy - ISTANBUL / TURKEY 34714

e-mail: editor@rumelide.com

phone: +90 $5057958124,+902167730616$ 


\begin{tabular}{l}
\hline and also in a task-oriented way. In this way, I aim for the student to \\
better develop four basic language skills through activities. (OK3) \\
Practical activities should be included. Turkish is a skill lesson. \\
Therefore, the important thing is to enable students to gain the skills. In \\
order to achieve this, game-based and practice-based activities should \\
be carried out in the context of four basic language skills. The student \\
should definitely be given the first example, and then expected to do the \\
activity. (LK5) \\
In the speaking and writing sections, I pay attention that activities are LK3 \\
progressive. It is very difficult to tell the student to speak or write about \\
a subject directly, even in the Turkish education for native students. For \\
this reason, I make preliminary preparations such as preparing the \\
student for the subject, giving clues about the topics to be written or \\
spoken, and presenting the draft. (LK7) \\
First of all, I think, there should be progressiveness in the activities. In \\
other words, achievements to be provided should be ensured through \\
step by step activities as the child internalizes. Instead of loading the \\
desired achievements into an activity, they should be distributed to the \\
required activity amount. (OK2)
\end{tabular}

In Table 9, the findings acquired as a result of the question "Can you talk about the aspects you paid attention to while preparing the activities in the coursebook?" are presented through 6 themes: achievement and functionality based, compliance with the steps of taxonomy, target audience, game and practice based, and progressiveness. Six participants took the achievements and functions specified in the Curriculum as a basis while preparing the activities. Five participants are preparing game and practice-based activities. When activities for the target language are gamified and given by involving the student in the process, the acquisition is easier. Language teaching is given to the student in a spiral structure. The prepared activities are also presented to the students in stages. Three participants are preparing their activities in line with this perspective. There are 4 participants who prepare their activities in accordance with the Bloom's Taxonomy. The participant given the code of OK1 was not included in any theme with the following opinion: "After preparing the activity, I try to do it myself first. I try to answer questions such as: "Did I get bored or have fun doing this activity?" In addition to these, if I have the opportunity, I try to get the opinions of people around me about the activity by showing them the activity. I can make corrections or changes on the activities according to the ideas expressed. It is always good for another eye to see. Because an error or lack of information can be overlooked by the author. Even if the author reads it again, s/he cannot see it."

It was also questioned within the scope of the research whether the prepared books should consist of a set consisting of coursebook, workbook and teacher's guidebook or just a coursebook. The obtained opinions are presented in Table 10.

Table 10. Opinions of Participants on How Coursebooks Should be Organized

\begin{tabular}{|c|c|c|}
\hline Theme & Expressed Statement & Participants \\
\hline & $\begin{array}{l}\text { It is important to have a workbook that supports the } \\
\text { coursebook in order to increase the efficiency of the activities } \\
\text { both in the classroom and at home. The teacher's guidebook, } \\
\text { on the other hand, is an essential resource in terms of being } \\
\text { used as a road-map for the teacher to understand the goals and } \\
\text { way of thinking of the coursebook and to get the highest level } \\
\text { of efficiency while implementing the activities. (OÖ2) }\end{array}$ & $\begin{array}{l}\mathrm{OÖ}_{1}, \mathrm{OÖ}_{4}, \mathrm{ILK}_{1}, \dot{I L K K}_{2} \text {, } \\
\text { ILLK} 3, \mathrm{OK}_{2}, \mathrm{OK}_{3}, \mathrm{OK}_{4}, \\
\mathrm{OK}_{5}, \mathrm{OK}_{6}, \mathrm{OK}_{7}, \mathrm{LK}_{2}, \\
\mathrm{LK}_{3}, \mathrm{LK}_{4}, \mathrm{LK}_{5}, \mathrm{LK}_{7}\end{array}$ \\
\hline & $\begin{array}{l}\text { All of these three books are a must have. The coursebook } \\
\text { process is important in that it is carried out together with the } \\
\text { student and forms the student part of the course. The teacher's }\end{array}$ & \\
\hline
\end{tabular}

RumeliDE Dil ve Edebiyat Araştırmaları Dergisi Osmanağa Mahallesi, Mürver Çiçeği Sokak, No:14/8 Kadıköy - ISTANBUL / TÜRKIYE 34714 e-posta: editor@rumelide.com tel: +90 505 7958124, +90 2167730616
Address

RumeliDE Journal of Language and Literature Studies

Osmanağa Mahallesi, Mürver Çiçeği Sokak, No:14/8

Kadıköy - ISTANBUL / TURKEY 34714

e-mail: editor@rumelide.com,

phone: +90 505 7958124, +90 2167730616 


\begin{tabular}{|c|c|}
\hline \multirow[t]{2}{*}{$\begin{array}{l}\text { Guidance (Guide) - } \\
\text { Extra Source - } \\
\text { Reinforcement }\end{array}$} & $\begin{array}{l}\text { guidebook is very important to provide new ideas to guide the } \\
\text { teacher who manages the process. On the other hand, the } \\
\text { workbook is highly valuable because it is such an important } \\
\text { point that language teaching cannot be satisfied with what is } \\
\text { taught only in the lesson. (ILK4) }\end{array}$ \\
\hline & $\begin{array}{l}\text { In my opinion, book sets prepared for foreigners should consist } \\
\text { of a coursebook, a workbook and a teacher's guidebook. The } \\
\text { workbook must be in the set. Because the language learner uses } \\
\text { the coursebook with the instructor. They can apply what they } \\
\text { learned in the coursebook to the workbook by themselves, test } \\
\text { their language learning level, and reinforce their knowledge. If } \\
\text { the teacher's guidebook is prepared in accordance with the } \\
\text { original, it shall guide the implementation of the coursebooks } \\
\text { and make the lesson interesting. The teacher's guidebook } \\
\text { should not only have answers of activities. It should be } \\
\text { prepared to guide the teacher in every step from the beginning } \\
\text { to the end of the lesson. (LK6) }\end{array}$ \\
\hline \multirow[t]{2}{*}{$\begin{array}{l}\text { Complementary } \\
\text { Individual } \\
\text { Activities }\end{array}$} & $\begin{array}{l}\text { The workbook also matters. However, my opinion is that this } \\
\text { is somewhat less important compared to the coursebook and } \\
\text { teacher's guidebook; because, as the author, while writing the } \\
\text { workbook, we prepare some activities on the topics we think } \\
\text { are missing while teaching the theme. The major person } \\
\text { dominating the classroom is the teacher, and I defend the idea } \\
\text { that it is the teacher who can see what the students in the } \\
\text { classroom fully understand and which topics they miss. In the } \\
\text { sections where the students have problem in understanding or } \\
\text { comprehending, the teacher can try to make up for these } \\
\text { deficiencies by preparing additional materials and worksheets. } \\
\text { (OK1) }\end{array}$ \\
\hline & $\begin{array}{l}\text { If there is a time that the student can spare for the workbook, I } \\
\text { think this time should be spent on extracurricular activities } \\
\text { planned by the teacher considering that there will not be any } \\
\text { interactive applications that support the coursebook or digital } \\
\text { opportunities where appropriate; because I think the } \\
\text { workbook is used as a continuation step of the traditional } \\
\text { education's understanding of homework, and today this should } \\
\text { be abandoned and practices for the use of language should be } \\
\text { encouraged through projects and tasks. I consider the } \\
\text { workbook as a boring repetitive piece of paper. (LK1) }\end{array}$ \\
\hline
\end{tabular}

In Table 10, the findings acquired as a result of the question "In your opinion, should the book sets prepared for foreigners consist of a coursebook, a workbook and a teacher's guidebook, or should it be just a coursebook? Can you explain your opinions with reasons?" are presented. Opinions were classified in the following themes: "Guidance (Guide) - Extra Source - Reinforcement and Complementary Individual Activities". 19 participants stated that the book sets should be given together with the coursebook, workbook and teacher's guidebook. The workbook is a necessary resource for the student to carry out both repetition and reinforcement. It is understood that the teacher's guide book is a guide that guides the teachers in the process. Participants with OK1 and LK1 codes stated that there is no need for a workbook; and instead, it is more appropriate for teachers to carry out individual activities for the deficiencies of students. The participant given the code of OÖ3 was not included in any theme with the following opinion: "Workbook is a material that can be preferred depending on the approach of the material / curriculum producers. In some book sets, the workbook is used as a homework book to repeat what students have learned in the classroom outside the school while in some of them, it is designed as a material prepared for the use of students who need it and includes activities as a continuation of the activities in the coursebook. To summarize, I think a book set aiming to teach a foreign language must necessarily include a coursebook and a teacher's guidebook, and it is optional

Adres

RumeliDE Dil ve Edebiyat Araştırmaları Dergisi Osmană̆a Mahallesi, Mürver Çiçeği Sokak, No:14/8 Kadıköy - İSTANBUL / TÜRKIYE 34714 e-posta: editor@rumelide.com tel: +90 $5057958124,+902167730616$
Address

RumeliDE Journal of Language and Literature Studies

Osmanağa Mahallesi, Mürver Çiçeği Sokak, No:14/8

Kadıköy - ISTANBUL / TURKEY 34714

e-mail: editor@rumelide.com

phone: +90 5057958124, +90 2167730616 
to use the workbook depending on the approach and aims. The participant stated that the workbook should be entirely dependent on aim-oriented preference.

\section{Conclusion and suggestions}

The results of this study, which aims to reveal the perceptions of the authors who continue the coursebook writing process based on the Curriculum for Teaching Turkish as a Foreign Language on the process of writing book, can be summarized as follows:

- The participants stated the principles to be considered in the coursebooks to be prepared for the teaching of Turkish as a foreign language in four main themes as being enabling students to be active, being appropriate for the child, progressiveness, and planning of language teaching.

- Considering the levels of language teaching, most of the participants agreed that it is difficult to produce content and activities at the beginner level. The authors explained the easiness in the process through the fact that the progression is in a spiral manner.

- Regarding the characteristics of the texts to be included in the coursebook, the participants stated their opinions in four themes as being Being Appropriate for the Aim, Achievement, Level, Theme and Student; Original, Up-to-date, Real; Being Appropriate for the Child; and The Relationship between Language and Culture. It is possible to say that the points stated by the participants coincide with those expressed in the Turkish course curriculum prepared for the native speakers (MEB, 2019).

- The points to be considered while preparing the activities for the coursebook were expressed by the participants as being achievement and functionality, compliance with the steps of taxonomy, characteristics of the target audience, being game and practice based, and progressiveness.

- Regarding the question whether the coursebooks should be organized as a set or as a standalone books, 19 of the participants stated that they should be organized as a set, including coursebook, workbook, and teacher's guidebook.

It is observed that there are many studies in the literature on the books/book sets used in teaching Turkish as a foreign language (Tok, 2013; Kılınç and Yenen, 2015; Gün, Akkaya and Kara, 2014; Ömeroğlu, 2016; Tiryaki and Kayatürk, 2017; Biçer and Kılıç, 2017; Ulutaş and Kara, 2019; Gün, Yalçın and Pişkin, 2019; Kalaycı and Durukan, 2019). Considering the conducted researches, it is observed that the existing books are evaluated from various aspects such as cultural transfer, activities, skills, and opinions of the users. In this study, it is aimed to bring a different perspective to the field by determining the opinions of authors who contribute to the books aiming to teach Turkish as a foreign language.

On the other hand, in their study Teaching Turkish as a Foreign Language According to the Views of Textbook Authors, Karagöl and Kurt (2021) revealed the opinions of the coursebook authors on teaching Turkish as a foreign language on the basis of curriculum, skills, grammar and vocabulary teaching. In this study carried out with a group of authors who prepared book sets for teaching Turkish by levels within the scope of formal education based on the "Curriculum for Teaching Teaching Turkish as a Foreign Language" prepared by the Turkish Maarif Foundation, the perceptions and opinions of the authors on the book writing process were determined. In this respect, in addition to its complementary nature to previous studies, it is considered that it can bring along a different perspective to the field in

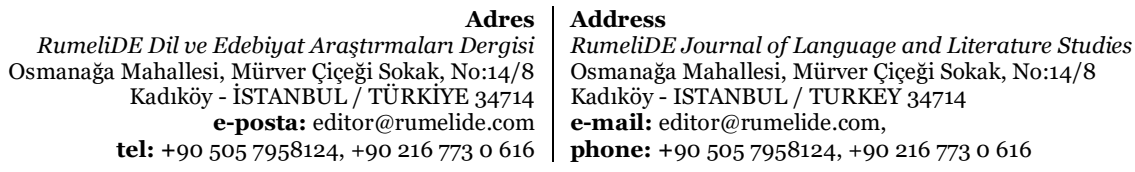


terms of reflecting the opinions of a study team writing books based on the curriculum and within the scope of formal education.

In line with the results obtained in the research, it can be presented as a suggestion that it is necessary to specify the criteria for the coursebooks to be prepared for the teaching of Turkish as a foreign language, that the authors who shall write books in this field are selected from those who have experience in teaching Turkish as a foreign language, that the authors should be provided with curriculum literacy trainings for the Curriculum for Teaching Turkish as a Foreign Language, and that the existing books should be revised in accordance with the Curriculum.

\section{Sources}

Ankara TÖMER (2015). Yabancı Dil Olarak Türkçe Öğretimi Programı (The Curriculum for Teaching Turkish as a Foreign Language), (M. Ertan Gökmen, Editor), Ankara, Ankara University Press.

Balcı, M. (2017). Türkçenin yabancı dil olarak öğretiminde temel kavramlar (Basic concepts in teaching Turkish as a foreign language). Hayati Develi, Cemal Yıldız, Mustafa Balcı, İbrahim Gültekin, Deniz Melanlığlu (Editors). In Uygulamalı Türkçenin yabancı dil olarak öğretimi el kitabı (The handbook of teaching applied Turkish as a foreign language) (p. 43-133). İstanbul: Kesit Publications.

Balcı, M. and Melanlığlu, D. (2020). On the curriculum of teaching Turkish as a foreign language. Krrkkale University Journal of Social Sciences, 10 (2), 173-198.

Biçer, N. and Kılıç, B. S. (2017). Evaluation of Text Books which are Used for Teaching Turkish to Syrian Students based on Teacher Opinions. Journal of Mother Tongue Education, 5(4), 649-663.

Biçer, N., Çoban, İ. and Bakır, S. (2014). The problems faced by the foreign students learning Turkish: Atatürk University Case. The Journal of International Social Research, 7 (19), 125-135.

Candaş Karababa, C. (2009). Teaching Turkish as a Foreign Language and Problems Encountered. Ankara University Journal of Faculty of Educational Sciences (JFES), 42 ( 2), 265-277.

Demirtaş, S. K. and Acer, E. K. (2016). Türkçe öğretiminde karşılaşılan sorunlara yönelik bir değerlendirme: Passau üniversitesi örneği (An evaluation of the problems encountered in teaching Turkish: The case of Passau University). Alpaslan Okur, Bekir İnce, İsmail Güleç (Editors). In Yabancllara Türkçe öğretimi üzerine araşttrma (Research on teaching Turkish to foreigners) (177-184). Sakarya: Sakarya University TÖMER Publications.

Durmus, M. (2013). Teaching Turkish to foreigners: problems, solutions and ideas on the future of teaching Turkish to foreigners. Adiyaman University Journal of Social Sciences Institute, Special Issue of Teaching Turkish, 6 (11), 207-228.

Durukan, E. and Maden, S. (2013). Yabancılara Türkçe öğretimi programı geliştirme (Developing a curriculum of teaching Turkish to foreigners). Mustafa Durmuş and Alpaslan Okur (Editors). In Yabancılara Türkçe öğretimi el kitabı (The handbook of teaching Turkish to foreigners), (p. 511526). Ankara: Grafiker Publications.

Gün, M., Yalçın, Ç. and Pişkin, B. S. (2019). Temel seviye yabancılara Türkçe öğretimi kitaplarında yer alan dil bilgisi konularının ve etkinliklerinin karşılaştırılması ve analizi (Comparison and analysis of grammar topics and activities in the coursebooks for teaching Turkish to foreigners at the basic level). Atatürk University Journal of Social Sciences Institute, (23), 2089-2101.

Gün, M., Akkaya, A. and Kara, Ö. T. (2014). The Assessment Of Turkish Class Books For Foreigners By The Instructors In Turkish Teaching Centers. Turkish Studies, 9 (6), 1-16.

Hengirmen, M. (1993). Yabancı dil öğretim yöntemleri ve TÖMER yöntemi (Foreign language teaching methods and TÖMER method). Ankara: Engin Publications.

Kalaycı, D. and Durukan, E. (2019). Comparing The Textbooks Of Teaching Turkish And English As A Foreign Language In Terms Of Learning Domains. International Journal of Turkish Literature Culture Education, 8 (4), 2162-2177.

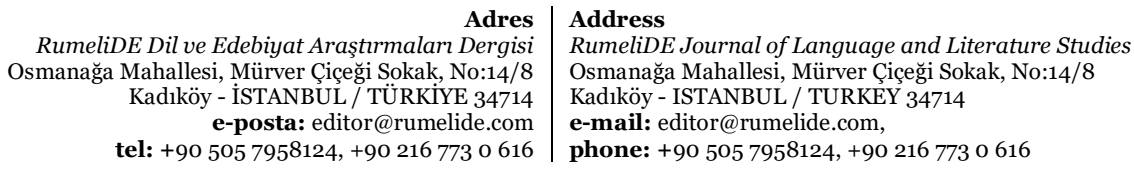


Perceptions of the authors writing book sets for teaching Turkish as a foreign language on the process of writing a book / $\dot{\mathrm{I}}$. Gültekin (pp. 55-76)

Karagöl, E. ve Kurt B. (2021). Ders kitabı yazarlarının görüşlerine göre yabancı dil olarak Türkçe öğretimi, Bayburt Eğitim Fakültesi Dergisi, Cilt:16 Sayı: Özel Sayı, 184-209.

Kılınç, H. H. and Yenen, E. T. (2015). Lecturers' Opinions Regarding Textbooks Used In Turkish Education For Foreigners. International Journal of Language Academy, 3 (4), 429-441.

Kolaç, E. (2003). The Evaluation of The Primary Education Fourth Grade Turkish Course Books With Regard to Teachers's Views. Journal of Uludağ University Faculty of Education, 17 (1), 105-137.

MEB (2006). İlköğretim Türkçe dersi (6, 7, 8. sinıflar) öğretim programı (Curriculum of primary education Turkish lesson (6th, 7th, 8th grades)). Ankara: Milli Eğitim Bakanlığı Publications.

MEB (2019). Türkçe dersi öğretim programı (ilkokul-ortaokul 1, 2, 3, 4, 5, 6, 7 ve 8. simıflar) (Curriculum of Turkish lesson (primary-secondary school 1st, 2nd, 3rd, 4th, 5th, 6th, 7th and 8th grades)). Ankara.

Ömeroğlu, E. (2016). Review Of The Textbooks Prepared For Teaching Turkish To Foreigners. Unpublished Doctoral Thesis. Sakarya University Institute of Educational Sciences, Sakarya.

Özbay, M. (2003). Türkçe öğretiminde hedef-araç ilişkisinin Ders kitabı örneğinde değerlendirilmesi (Evaluation of the target-tool relationship in Turkish teaching in the example of coursebook). TÜBAR-XIII-Spring.

Tiryaki, E. N. and Kayatürk, N. (2017). Evaluation Of Listening Texts In Coursebooks Of Teaching Turkish As A Foreign Language In Terms Of Implicit Meaning (Istanbul B1-B2 Level Course). Mustafa Kemal University Journal of Graduate School of Social Sciences, 14 (39), 300-319.

Tok, M. (2013). Assessing Writing Studies in the Textbooks of Teaching Turkish to Foreign. Uşak University Journal of Social Sciences, 6 (1), 249-279.

TYDÖP (2020). Türkçenin Yabancı Dil Olarak Öğretim Programı (The Curriculum for Teaching Turkish as a Foreign Language). İstanbul: TMV Publications.

Ulutaş, M. and Kara, M. (2019). Investigation Of Text Comprehension Questions In Teaching Turkish As A Foreign Language Textbooks According To Revised Bloom Taxonomy. International Journal of Turkish Literature Culture Education, 8 (4), 2198-2214.

Yalçın, S. (1994). The effect of the textbook written according to the principles of prose learning on the student achievement. Unpublished Doctoral Thesis. Hacettepe University Graduate School of Social Sciences, Ankara.

Yıldırım, A. and Şimşek, H. (2008). Sosyal bilimlerde nitel araştırma yöntemleri (Qualitative research methods in social sciences). Ankara: Seçkin Publications.

RumeliDE Dil ve Edebiyat Araştırmaları Dergisi Osmanağa Mahallesi, Mürver Çiçeği Sokak, No:14/8 Kadıköy - İSTANBUL / TÜRKIYE 34714 e-posta: editor@rumelide.com tel: +90 $5057958124,+902167730616$
Address

RumeliDE Journal of Language and Literature Studies

Osmanağa Mahallesi, Mürver Çiçeği Sokak, No:14/8

Kadıköy - ISTANBUL / TURKEY 34714

e-mail: editor@rumelide.com,

phone: +90 $5057958124,+902167730616$ 